\title{
Arsenic-transforming microbes and their role in biomining processes
}

\author{
L. Drewniak • A. Sklodowska
}

Received: 15 October 2012 / Accepted: 19 December 2012 / Published online: 9 January 2013

(C) The Author(s) 2013. This article is published with open access at Springerlink.com

\begin{abstract}
It is well known that microorganisms can dissolve different minerals and use them as sources of nutrients and energy. The majority of rock minerals are rich in vital elements (e.g., P, Fe, S, Mg and Mo), but some may also contain toxic metals or metalloids, like arsenic. The toxicity of arsenic is disclosed after the dissolution of the mineral, which raises two important questions: (1) why do microorganisms dissolve arsenic-bearing minerals and release this metal into the environment in a toxic (also for themselves) form, and (2) How do these microorganisms cope with this toxic element? In this review, we summarize current knowledge about arsenic-transforming microbes and their role in biomining processes. Special consideration is given to studies that have increased our understanding of how microbial activities are linked to the biogeochemistry of arsenic, by examining (1) where and in which forms arsenic occurs in the mining environment, (2) microbial activity in the context of arsenic mineral dissolution and the mechanisms of arsenic resistance, (3) the minerals used and technologies applied in the biomining of arsenic, and (4) how microbes can be used to clean up post-mining environments.
\end{abstract}

Keywords Arsenic minerals $\cdot$ Microbial activity $\cdot$ Arsenite oxidation $\cdot$ Arsenate reduction $\cdot$ Bioleaching .

Bioremediation

Responsible editor: Robert Duran

L. Drewniak $(\square) \cdot$ A. Sklodowska

Laboratory of Environmental Pollution Analysis,

Faculty of Biology, University of Warsaw, Miecznikowa 1,

02-096 Warsaw, Poland

e-mail: ldrewniak@biol.uw.edu.pl

\section{Introduction}

An ongoing challenge for the mining industry is the development and application of efficient, low-cost and environmentally friendly methods of metal recovery. Considerable effort is currently devoted to the improvement of existing technologies, particularly those intended for (1) metal recovery from low-grade ores, which has not been economic for many years, and (2) mine and wastewater treatment. A well-recognized way of extracting metals from mineral resources not accessible by conventional mining is the use of methods based on microbial activity. Microbes permit the recovery of metals from primary mineral deposits and from secondary raw materials like mine tailings, which may contain only trace amounts of the desired elements (especially precious metals). In addition, biomining techniques are generally less energy-intensive and less polluting than most non-biological procedures.

The most common biomining processes involve oxidative dissolution of minerals, leading to the solubilization of some metal compounds, and other become more accessible to chemical extraction but remain in an insoluble form (Rawlings 2011). Microbiological oxidative dissolution of minerals is mainly produced by the oxidation of iron, sulfur, or both of these typically results in the release of accompanying elements (e.g., oxidation of FeAsS leads to the release of iron and arsenic). In addition to desired metals, the oxidation of sulfur and iron minerals may sometimes cause the release of environmentally hazardous elements. One example of such troublesome deposits are minerals containing arsenic, a toxic metalloid whose extraction is of little commercial importance.

In this review, we examine the microbial dissolution of arsenic-bearing minerals as a side effect of biomining processes, with special emphasis on (1) the primary and 
secondary arsenic minerals that are the most abundant and dominant in mining environments, particularly those playing key roles in microbial life cycles, (2) the current state of knowledge on microbial activity in the context of arsenic mineral dissolution and mechanisms of arsenic resistance, (3) the minerals used and technology applied in biomining of arsenic-bearing minerals, and (4) how microbes are used to clean up post-mining environments.

\section{Arsenic minerals in mining environments}

Arsenic is widely distributed in the Earth's crust, occurring in trace amounts (average crustal abundance $=1.5 \mathrm{mg} / \mathrm{kg}$ ), predominantly in minerals of igneous and sedimentary rocks and soils (Plant et al. 2005). Some arsenic-bearing minerals, such as arsenides and sulfarsenides, are considered nontoxic because they are highly insoluble. Problems arise when these primary minerals break down and enter into solution or form more soluble species such as oxides (Vaughan 2006). Arsenic can be mobilized by dissolution into water or emitted into the atmosphere through natural processes as well as anthropogenic activity. Of the many causes of arsenic contamination microbial activity, mining and smelting operations seem to be the most significant.

A thorough understanding of arsenic geochemistry is necessary to be able to predict the likely impact of and potential risks associated with the use of microbes in biomining processes. A key question is where and in which form does arsenic occur in the mining environment? Knowledge concerning the type of minerals as well as the physical and chemical conditions occurring in the mine environment is vital in order to study how microbial activities are linked to the biogeochemistry of arsenic.

\section{Arsenic-bearing minerals}

More than 200 minerals that contain arsenic are found in nature (Hoang et al. 2010). Arsenic occurs mainly as arsenides, sulfides, oxides, arsenates and arsenites. Most of these minerals are found in close association with metals such as $\mathrm{Fe}, \mathrm{Cu}, \mathrm{Co}, \mathrm{Ni}, \mathrm{Cd}, \mathrm{Pb}, \mathrm{Ag}$ and $\mathrm{Au}$.

The most abundant arsenic ore minerals are As sulfides, including arsenopyrite (FeAsS), realgar $\left(\mathrm{As}_{4} \mathrm{~S}_{4}\right)$ and orpiment $\left(\mathrm{As}_{2} \mathrm{~S}_{3}\right)$. These primary arsenic minerals are formed only under high temperature conditions in the Earth's crust and occur in hydrothermal and magmatic ore deposits. Interestingly, orpiment- and realgar-like minerals can be formed in sulfate-reducing environments, probably by processes requiring microbiological sulfur and arsenic reduction (O'Day et al. 2004). An important feature of each mineral is its stability in the face of weathering and bioweathering processes. The structure of arsenic sulfide minerals is stabilized by (1) covalent bonds between arsenic and sulfur, (2) coordination bonds between iron and arsenic or sulfur (O’Day 2006), and (3) van der Waals forces between molecular units (Mullen and Nowacki 1972). Other transition metals, such as $\mathrm{Co}, \mathrm{Ni}$ and $\mathrm{Cu}$, also combine with arsenic and sulfur to form a variety of minor sulfides and sulfosalts, often with extensive solid solution (Table 1). Sulfide minerals are also associated with a number of arsenides, including arsenic structures with $\mathrm{Fe}, \mathrm{Co}, \mathrm{Ni}$ and $\mathrm{Cu}$. These minerals are typically rare and occur in hydrothermal and magmatic ore deposits. Similar to sulfides, the chemical bonds in arsenides are covalent. It is noteworthy that these minerals often form solid solutions with each other and with sulfide minerals in structural arrangements of common sulfides (e.g., pyrite, pyrrhotite, marcasite, galena).

Weathering and hydrothermal alteration of these primary minerals is thought to produce secondary arsenic minerals: the arsenic (III) oxides (arsenites) and arsenic (V) oxides (arsenates) (Table 2). Simple arsenic (III) oxides (arsenolite and claudetite) occur as products of arsenic sulfide weathering, but they are more commonly produced by the roasting of arsenic-bearing ore minerals or coal. Due to their similar size and charge, arsenic (V) minerals (arsenates) are usually considered as a subclass of the phosphate minerals (O'Day 2006), and as a result of this similarity, arsenate minerals occur in a variety of arsenic-rich soils and oxidized environments. Secondary arsenic minerals occur as weathering products of arsenic-containing sulfidic metal deposits, where the sulfidic minerals are often coated with layers of oxidized and hydrated arsenate minerals. The most common secondary arsenic mineral is scorodite. Less common but more environmentally important arsenic minerals are found in mine-waste heaps and other types of industrial deposit. Other recognized secondary arsenic minerals are arsenolite, claudetite, erythrite, kankite and mimetite (Table 2). An excellent review of these minerals and their origin was presented in a special edition of Elements in 2006 (vol. 2, no. 2).

Secondary arsenic minerals exhibit a wide range of solubility. For example, arsenolite and claudetite, and some calcium arsenates (haidingerite, pharmacolite), are highly soluble in water, whereas some iron arsenates, such as beudantite, pharmacosiderite and scorodite, are relatively insoluble. Sparingly soluble minerals can effectively immobilize arsenic in contaminated sites and their precipitation decreases the amount of arsenic in the water. On the other hand, the re-dissolution of secondary arsenic minerals as a result of various environmental factors ( $\mathrm{pH}$ increase, temperature, supply of new chemical compounds with water) and especially microbial activity, may greatly affect the level of contamination of ground and surface waters by arsenic species (Drahota and Filippi 2009). 
Table 1 Primary arsenic-bearing minerals ${ }^{\mathrm{a}}$

\begin{tabular}{|c|c|c|}
\hline Name & $\begin{array}{l}\text { Chemical } \\
\text { formula }\end{array}$ & $\begin{array}{l}\text { (1) Common impurities } \\
\text { (2) Mining uses } \\
\text { (3) Environment }\end{array}$ \\
\hline Arsenopyrite & FeAsS & $\begin{array}{l}\text { (1) Pyrite, siderite and sulfides of } \mathrm{Ag}, \mathrm{Au}, \mathrm{Co}, \mathrm{Ni}, \mathrm{Sb}, \mathrm{Cu}, \mathrm{Pb} \\
\text { (2) Most common arsenic-bearing mineral and minor ore of gold } \\
\text { (3) High temperature ore veins, pegmatites, contact metamorphic rocks, and rarely in igneous basalt rocks }\end{array}$ \\
\hline Orpiment & $\mathrm{As}_{2} \mathrm{~S}_{3}$ & $\begin{array}{l}\text { (1) Realgar, calcite, barite, stibnite, gypsum, cinnabar and sulfides of } \mathrm{Au}, \mathrm{Ag}, \mathrm{Cu}, \mathrm{Pb} \\
\text { (2) Commonly as an alteration product of arsenic minerals, especially realgar } \\
\text { (3) Low temperature hydrothermal veins (fractures in rock in which hot water has precipitated minerals), hot springs } \\
\text { and as sublimates from gases emitted from volcanic fumaroles }\end{array}$ \\
\hline Realgar & $\begin{array}{l}\mathrm{AsS} / \\
\mathrm{As}_{4} \mathrm{~S}_{4}\end{array}$ & $\begin{array}{l}\text { (1) Orpiment, calcite, stibnite and other metal sulfide ores } \\
\text { (2) An important ore of arsenic } \\
\text { (3) Low temperature hydrothermal veins, volcanic hot springs, arid borate deposits and metamorphic marble pockets }\end{array}$ \\
\hline Loollingite & $\mathrm{FeAs}_{2}$ & $\begin{array}{l}\text { (1) Arsenopyrite, pyrite, chalcopyrite, pyrrhotite, biotite, sodalite, calcite, siderite, magnetite, galena, sphalerite, } \\
\text { (2) Found together with other arsenic minerals and is thus a minor ore of arsenic } \\
\text { (3) In mesothermal deposits associated with other sufides and calcite gangue; also found in pegmatites }\end{array}$ \\
\hline Enargite & $\mathrm{Cu}_{3} \mathrm{AsS}_{4}$ & $\begin{array}{l}\text { (1) Chalcocite, chalcopyrite, covellite, pyrite, bornite, galena, sphalerite, tennantite, and other metal sulfides } \\
\text { (2) A rare copper mineral } \\
\text { (3) Moderate-temperature hydrothermal vein deposits. Late stage mineral in low temperature deposits }\end{array}$ \\
\hline
\end{tabular}

${ }^{\text {a }}$ Information about minerals was taken from the mindat.org database

\section{The processing of ores as a source of arsenic in the environment}

Arsenic is present in the mining environment not only in the rock minerals, but also as water-soluble compounds and in gaseous form. Mining is focused on the recovery of elements and materials from mineral deposits, but during the process, side effects like the release of contaminants can occur. Mining and the processing of As-bearing minerals may contribute to the release of high concentrations of arsenic into the water, soil and air. Coal combustion in power stations, and the roasting and smelting of ores in non-ferrous metal smelters also cause the release of arsenic into the atmosphere (Han et al. 2003; Yudovic and Ketris 2005).

The oxidation of sulfide minerals in hydrometallurgical and biometallurgical processes causes the acidification of waters and their enrichment in sulfate anions and heavy metals (Johnson 2003). The presence of extremely high levels of toxic metals in acidic mine waters, commonly known as acid mine drainage (AMD) or acid rock drainage (ARD) waters, constitutes one of the main environmental problems faced by the world's mining industries. Arsenic is present in many AMD or ARD waters as a result of the oxidation of arsenic-bearing sulfide minerals. This two-step process is described by the following equations:

$$
\begin{aligned}
\mathrm{FeAsS}(\mathrm{s}) & +11 / 4 \mathrm{O}_{2}(\mathrm{aq})+3 / 2 \mathrm{H}_{2} \mathrm{O}(\mathrm{aq})<=>\mathrm{Fe}^{2+}(\mathrm{aq}) \\
& +\mathrm{SO}_{4}^{2-}(\mathrm{aq})+\mathrm{H}_{3} \mathrm{AsO}_{3}(\mathrm{aq})
\end{aligned}
$$

$\mathrm{H}_{3} \mathrm{AsO}_{3}+1 / 2 \mathrm{O}_{2}(\mathrm{aq})<=>\mathrm{H}_{2} \mathrm{AsO}_{4^{-}}+\mathrm{H}+$

Mine spoils and wastes from ore treatment plants have often been dumped into or near streams. The fine fraction of ash (flying ashes) produced by smelting of ore concentrates causes the widespread airborne dispersal of arsenic, thus contaminating soil and streams over a wide area. Once
Table 2 Common secondary arsenic-bearing minerals

\begin{tabular}{llll}
\hline Arsenic (III) oxides & \multicolumn{3}{c}{ Arsenic (V) oxides } \\
\hline Arsenolite & $\mathrm{As}_{2} \mathrm{O}_{3}$ & Scorodite & $\mathrm{Fe}^{3+}\left(\mathrm{AsO}_{4}\right) \cdot 2 \mathrm{H}_{2} \mathrm{O}$ \\
Claudetite & $\mathrm{As}_{2} \mathrm{O}_{3}$ & Kankite & $\mathrm{Fe}^{3+}\left(\mathrm{AsO}_{4}\right) \cdot 3.5 \mathrm{H}_{2} \mathrm{O}$ \\
Leiteite & $\mathrm{ZnAs}_{2} \mathrm{O}_{4}$ & Symplesite & $\mathrm{Fe}^{3+}{ }_{3}\left(\mathrm{AsO}_{4}\right)_{2} \cdot 8 \mathrm{H}_{2} \mathrm{O}$ \\
Trippkeite & $\mathrm{Cu}^{2+} \mathrm{As}_{2} \mathrm{O}_{4}$ & Conichalcite & $\mathrm{CaCu}$ \\
Manganarsenite & $\mathrm{Mn}^{2+}{ }_{3} \mathrm{As}_{2} \mathrm{O}_{4}(\mathrm{OH})_{4}$ & Erythrite & $\mathrm{Co}_{3}\left(\mathrm{AsO}_{4}\right) \cdot 8 \mathrm{H}_{2} \mathrm{O}$ \\
Gebhardite & $\mathrm{Pb}_{8}\left(\mathrm{As}_{2} \mathrm{O}_{5}\right)_{2} \mathrm{OCl}_{6}$ & Mimetite & $\mathrm{Pb}_{5}\left(\mathrm{AsO}_{4}\right)_{3}(\mathrm{Cl})$ \\
\hline
\end{tabular}


distributed by these means, arsenic can produce toxic effects in nature.

The 1,000-year history of mining and smelting has left a legacy of arsenic pollution in several regions of Europe and in USA. Contaminated sites in Devon and Cornwall in the UK display one of the world's highest concentrations of arsenic in soil of up to 2,500 ppm, compared with normal values of less than $40 \mathrm{ppm}$ found elsewhere in the UK and the rest of the world (WHO). Similarly, in south western Poland in the area of the Zloty Stok ancient gold mine (active since the 13th century) and in the neighboring Lower Silesia district, very high levels of arsenic have been recorded in soil and water sediments $(3,400$ and 6,125 ppm, respectively) (Lis and Pasieczna 1995; Drewniak, unpublished data).

\section{Microbial activity linked to the biogeochemistry of arsenic}

Microorganisms can dissolve different minerals and use them as a source of nutrients and energy. Some microbes interact with minerals in order to obtain inorganic substrates (e.g., $\mathrm{Fe}^{2+}$ or $\mathrm{S}^{2-}$ ) as their only source of energy. Others utilize organic material and use inorganic compounds (like $\mathrm{O}_{2}, \mathrm{Fe}^{3+}, \mathrm{SO}_{4}{ }^{2-}$ ) as terminal electron acceptors. Sulfide minerals are also a source of enzyme cofactors such as $\mathrm{Mo}, \mathrm{Cu}, \mathrm{Zn}, \mathrm{Mg}$, and minerals such as apatite can supply phosphorus, required for the synthesis of DNA, RNA, ATP and phospholipids (Banfield et al. 1999).

The majority of minerals in rock represent a rich source of vital elements, but some may contain toxic metals or metalloids, like arsenic. The fact that the toxicity of arsenic is disclosed after the dissolution of the mineral raises two important questions: (1) why do microorganisms dissolve arsenic-bearing minerals and release this metal into the environment in a toxic (also for themselves) form, and (2) how do they cope with this toxic element?

\section{Microbial mineral colonization and nutrient extraction}

Elements present in the rocks become available only when they are extracted from the crystal lattice. Microorganisms have evolved different mechanisms of nutrient uptake from minerals. The primary mechanism is connected with colonization and involves (1) physical penetration of the rock surface causing disaggregation of the mineral (Konhauser 2007), and (2) dissolution mediated by organic agents produced by the cells (Drever and Stillings 1997)

Physical processes contribute to surface roughing (by etching and pitting), detachment, separation and crushing of some constituents of mineral grains along cleavage planes
(Barker et al. 1997). Exopolysaccharides (EPS) produced by microorganisms also play an important role in the mineral colonization process. As a consequence of EPS production, bacteria can attach to exposed mineral surfaces, then coat them with EPS and physically disrupt mineral grains. EPS aid the retention of water, which in turn has a direct impact on mineral fracturing and supports fuel hydrolysis and other chemical reactions (Welch et al. 1999). Moreover, EPS can serve as substrates for other (heterotrophic) bacteria, which produce organic agents that promote the chemical dissolution of the underlying minerals (Konhauser 2007). Such microbial "dissolution agents" include organic acids and organic ligands that are produced by cells and excreted when growth is limited by the absence of an essential nutrient.

Organic acids increase mineral dissolution both directly by destabilizing metal-oxygen bonds (protonation reaction) and by promoting the formation of a metal chelate by anions from acids dissociation, and indirectly by lowering the solution saturation state as a result of the complexing of metals in solution (Bennett et al. 1988). An interesting example of mineral dissolution mediated by organic acids produced by microbes is the bioweathering of arsenic-containing apatite $\left(\mathrm{Ca}_{2}\left(\mathrm{PO}_{4}\right)_{3}(\mathrm{~F}, \mathrm{Cl}, \mathrm{OH})\right)$. Mailloux et al. (2009) showed that Burkholderia fungorum (ATCC BAA-463) growing in a phosphorus-limited medium could release arsenic from apatite through the production of gluconic acid. These authors showed that arsenic levels systematically increased along with those of calcium and phosphorus (indicating dissolution of apatite), while the decrease in glucose was accompanied by a simultaneous increase in gluconic acid (indicating microbial respiration). More importantly, speciation analysis failed to demonstrate the occurrence of redox arsenic reactions, indicating that arsenic release was independent from bioreduction. Arsenic release is also likely to occur during the weathering of other minerals such as feldspars, biotite and hornblende (Brantley et al. 2001; Rogers and Bennett 2004; Rogers et al. 1998; Uroz et al. 2007).

Similar to organic acids, organic ligands may form strong complexes with metal cations. These compounds can chelate metal ions and also bind to atoms on the mineral surface. Among the most common organic ligands produced by microorganisms are siderophores: high-affinity, metalbinding compounds secreted outside the cell envelope. It was originally thought that these low molecular weight complexing agents are excreted by bacteria and fungi only under conditions of iron deficiency (Raymond et al. 1984). However, it is now clear that siderophores are also able to effectively bind many other metal and metalloids including Mg, Mn, Cr(III), Ga(III), Pl(IV), Pb, Cd, Zn, Cu, Ni, U(VI), Co, Sn and As (Aiken et al. 2003; Yarnell and Washington 2003; Malik 2004; Peyton and Apel 2005; Nair et al. 2007). Studies on siderophores produced by Pseudomonas 
azotoformans have shown that these multi-metal complexing ligands display strain-specific patterns of affinity for the complexation of metals and metalloids: $\mathrm{Cd}^{2+}=\mathrm{Ni}^{2+}=\mathrm{Pb}^{2+}=$ $\mathrm{Sn}^{2+}=\mathrm{AsO}_{4}{ }^{-2}=\mathrm{AsO}_{2}{ }^{-1}>\mathrm{Mn}^{2+}=\mathrm{Co}^{2+}=\mathrm{Cu}^{2+}=\mathrm{Fe}^{3+}$ (Nair et al. 2007). We recently confirmed that siderophores produced by bacteria may not only bind to metal ions in solution, but also to metals/metalloids on the mineral surface (Drewniak et al. 2010). Arsenic-tolerant Pseudomonas spp. strains were found to produce iron-binding compounds that help them to uptake iron from insoluble arsenopyrite and other minerals of gold mine rocks. During this process, arsenic is mobilized from the solid to the aqueous phase.

\section{Chemolithoautotrophic pathways}

Microbial colonization of minerals also improves the accessibility of sites containing a reduced form of energy substrate. Primary arsenic minerals (which contain reduced forms of elements) may be used as a source of energy (as an electron donor) by a number of physiologically and phylogenetically diverse microorganisms. Chemolithoautotrophic microorganisms have evolved a metabolic pathway for the oxidation of reduced minerals (such as arsenopyrite, realgar or enargite), coupled to a terminal electron acceptor, for the production of ATP. Depending on the mechanisms of mineral utilization (and their constituent elements), different forms of arsenic are released into the environment.

Important members of microbial consortia in most mining environments are the iron and sulfur oxidizers. These microbes promote the dissolution of arsenic-bearing minerals by oxidation of associated iron or sulfur (or both) and release a range of compounds of varying final arsenic oxidation state, depending upon the type of mineral and the oxidizing conditions. The prokaryotes that enhance the oxidation of $\mathrm{Fe}$ - and S-bearing minerals are dominated by acidophilic microorganisms. Among them, the most effective in arsenic mineral biooxidation are the mesophilic microorganisms Acidithiobacillus ferroxidans, Acidithiobacillus thioxidans and Leptospirillum ferroxidans (Hackl and Jones 1997). Several direct or indirect mechanisms of oxidative dissolution of arsenopyrite (FeAsS) have been proposed (for a comprehensive review of arsenopyrite oxidation, see Corkhill and Vaughan 2009). Of particular note are arsenopyrite oxidation reactions enhanced by bacterial metabolism discussed by Collinet and Morin (1990). These authors described the microbial oxidation of FeAsS in the presence of oxygen, which results in the production of arseneous $\left(\mathrm{H}_{3} \mathrm{AsO}_{3}\right)$ and arsenic acids $\left(\mathrm{H}_{3} \mathrm{AsO}_{4}\right)$ (Eqs. 3 and 4):

$2 \mathrm{FeAsS}+5.5 \mathrm{O}_{2}+3 \mathrm{H}_{2} \mathrm{O} \rightarrow 2 \mathrm{H}_{3} \mathrm{AsO}_{3}+2 \mathrm{FeSO}_{4}$
$2 \mathrm{FeAsS}+6.5 \mathrm{O}_{2}+3 \mathrm{H}_{2} \mathrm{O} \rightarrow 2 \mathrm{H}_{3} \mathrm{AsO}_{4}+2 \mathrm{FeSO}_{4}$

$2 \mathrm{FeAsS}+0.5 \mathrm{O}_{2}+\mathrm{H}_{2} \mathrm{SO}_{4} \rightarrow 2 \mathrm{Fe}_{2}\left(\mathrm{SO}_{4}\right)_{3}+\mathrm{H}_{2} \mathrm{O}$

Microbial oxidation of arsenopyrite can be also realized by the following indirect mechanism described by Sadowski et al. (2000):

$\mathrm{FeAsS}+5 \mathrm{Fe}^{3+}+3 \mathrm{H}_{2} \mathrm{O} \rightarrow 6 \mathrm{Fe}^{2+}+\mathrm{H}_{3} \mathrm{AsO}_{3}+3 \mathrm{H}^{+} \mathrm{S}^{0}$

Under extremely strong oxidizing condition, sulfur is completely oxidized to $\mathrm{S}(\mathrm{VI})$ and As(III) is rapidly oxidized to $\operatorname{As}(\mathrm{V})$ :

$$
\begin{aligned}
\mathrm{FeAsS}+13 \mathrm{Fe}^{3+}+8 \mathrm{H}_{2} \mathrm{O} \rightarrow & 14 \mathrm{Fe}^{2+}+\mathrm{H}_{3} \mathrm{AsO}_{4} \\
& +13 \mathrm{H}^{+} \mathrm{SO}_{4}{ }^{2-}
\end{aligned}
$$

Acidophilic microorganisms can also release arsenic from realgar $\left(\mathrm{As}_{2} \mathrm{~S}_{2}\right)$ via similar mechanisms, i.e., (a) direct oxidation of realgar, (b) oxidation of realgar in the presence of ferrous iron, and (c) oxidation of realgar in the presence of sulfur (Chen et al. 2011).

Arsenic minerals can also be oxidized at circumneutral $\mathrm{pH}$ by sulfur and arsenite oxidizing microbes. Rhine et al. (2008) reported that under aerobic conditions at circumneutral $\mathrm{pH}$, strain WAO (closely related to Bosea thiooxidans) could mediate oxidation of sulfide in the pyrite lattice leading to the release of pyrite-bound arsenic. Moreover, the oxidation of aqueous As(III) to As(V) by this aerobic bacterium further enhanced arsenic mobilization from the solid phase. Arsenopyrite (FeAsS) oxidation by strain WAO was also shown to result in microbially enhanced mobilization of arsenic and complete oxidation of arsenic and sulfur to stoichiometric amounts of arsenate and sulfate (Rhine et al. 2008). Studies in our laboratory have demonstrated arsenopyrite oxidation by the arsenite oxidizing strain Sinorhizobium sp. M14 (Drewniak et al. 2010). However, speciation analysis of As(III) in the culture supernatant showed that oxidation of the released arsenic was incomplete. Furthermore, a dark orange scorodite-like precipitate formed on the surface of the arsenopyrite, indicating that at circumneutral $\mathrm{pH}$, the arsenic was co-precipitated with $\mathrm{Fe}$ (III) (released from arsenopyrite) and again immobilized. Apart from the two studies described above, there has been little research on the mechanisms of arsenic-bearing mineral dissolution mediated by arsenite oxidizers. At present, the mineral dissolution potential of arsenic oxidizing microbes can only be estimated by analyzing recently published data about As(III) oxidation processes in the aqueous phase.

For most chemolithoautotrophic bacteria, the oxidation of arsenite (acting as an electron donor) is coupled to the respiratory electron transport chain and the reduction of oxygen, and is connected with the acquisition of energy 
for the assimilation of $\mathrm{CO}_{2}$ and cell growth (Santini et al. 2000; Muller et al. 2003; Battaglia-Brunet et al. 2006; Drewniak et al. 2008). Other strains have been identified that are capable of the anaerobic autotrophic oxidation of arsenite (Oremland et al. 2002; Rhine et al. 2006; Sun et al. 2009, 2010). These bacteria can oxidize As(III) in anoxic conditions using nitrate as the final electron acceptor (Rhine et al. 2006). Chlorate compounds may represent an alternative electron acceptor supporting microbial oxidation of arsenite. Sun et al. (2010) showed that two isolates, Dechloromonas sp. Strain ECC1-pb1 and Azospira sp. Strain ECC1-pb2, could grow by linking the oxidation of As(III) to $\mathrm{As}(\mathrm{V})$ with the reduction of $\mathrm{ClO}_{3}{ }^{-}$. Microbial transformation of $\mathrm{As}(\mathrm{III})$ to the less toxic form $\mathrm{As}(\mathrm{V})$ is also mediated by heterotrophic arsenite oxidizers, which require an organic carbon source for growth. Interestingly, despite the fact that arsenite oxidation is a exothermic reaction $\left[2 \mathrm{H}_{3} \mathrm{AsO}_{3}+\mathrm{O}_{2} \rightarrow \mathrm{HAsO}_{4}{ }^{2-}+\mathrm{HAsO}_{4}{ }^{-}+3 \mathrm{H}^{+}\left(\Delta G_{0}{ }^{\prime}=\right.\right.$ $-256 \mathrm{kj} / \mathrm{Rx})$ ], heterotrophic bacteria appear only to use it for detoxification and not to acquire energy for cell growth.

\section{Dissimilatory reduction processes}

The release of arsenic from As-bearing minerals by reductive dissolution is thought to be the dominant process for arsenic displacement from secondary minerals. Under reducing conditions, microorganisms can use arsenic compounds as a terminal electron acceptor in arsenic respiration (Laverman et al. 1995; Krafft and Macy 1998; Switzer Blum et al. 1998). In this process, the reduction of $\mathrm{As}(\mathrm{V})$ to $\mathrm{As}(\mathrm{III})$ is accompanied by oxidation of organic or inorganic substrates and the synthesis of ATP. The oxidation of organic compounds combined with the reduction of arsenates to arsenites is energetically favorable due to the redox potential of $\mathrm{As}(\mathrm{V}) / \mathrm{As}(\mathrm{III})$, which is $+135 \mathrm{mV}$. The most common organic electron donors used by these bacteria are acetate, lactate, butyrate, pyruvate, malate, glycerol and ethanol (Newman et al. 1998). Dissimilatory reduction of arsenate can also be coupled with oxidation of inorganic compounds, as in the case of the chemoautotrophic bacterial strain MLMS-1, which is able to reduce As(V) to arsenite using sulfides as the electron donor (Hoeft et al. 2004). One extremely important feature of dissimilatory arsenatereducing microbes is their ability to use additional electron acceptors, such as Fe(III), sulfate, thiosulfate, elemental sulfur, nitrate, DMSO and others (Stolz and Oremland 1999; Paez-Espino et al. 2009). Alkaliphilus oremlandii is one such strain that can use arsenate and thiosulfate as terminal electron acceptors with acetate, pyruvate, formate, lactate, glycerol, or fructose as the electron donor (Fisher et al. 2008). Another strain with a broader dissimilatory metabolism is Desulfuribacillus alkaliarsenatis, which apart from arsenate, can also grow by elemental sulfur or thiosulfate reduction using $\mathrm{H}_{2}$, formate, pyruvate or lactate as the electron donor (Sorokin et al. 2012). The dissimilatory arsenate-, selenate-, selenite-, nitrate- and nitrite-reducing bacterium Desulfurispirillum indicum strain S5 can utilize multiple respiratory pathways (Rauschenbach et al. 2011). Another very interesting group of prokaryotic microorganisms are those able to catalyze both types of redox reaction. One example is Thermus strain HR13, which oxidizes As (III) to $\mathrm{As}(\mathrm{V})$ under aerobic conditions, and uses arsenates as the terminal electron acceptor under anaerobic conditions (Gihring and Banfield 2001).

For most of the aforementioned arsenate-respiring bacteria, only reduction processes occurring in the aqueous phase have been studied. However, there is evidence that bacteria can dissolve arsenic-bearing minerals by reductive dissolution. The utilization of scorodite $\left(\mathrm{FeAsO}_{4} \cdot 2 \mathrm{H}_{2} \mathrm{O}\right)$ as a source of arsenate acting as an electron acceptor has been described for Desulfotomaculum auripigmentum strain OREX-4. This strain was shown to use acetate as an electron donor and reduce arsenate from scorodite in a dissimilatory way (Newman et al. 1997). Another interesting example is Sulfurospirillum barnesii SES-3, which is able to grow anaerobically using ferric iron or arsenate as terminal electron acceptors. Zobrist et al. (2000) demonstrated that S. barnesii could reduce arsenate adsorbed onto the surface of ferrihydrite. The reduction of $\mathrm{Fe}(\mathrm{III})$ in ferrihydrite to soluble $\mathrm{Fe}$ (II) was also observed, but dissolution of the ferrihydrite was not necessary for the reduction of adsorbed arsenate. Reducing conditions also promote the dissolution and transformation of accompanying elements - mainly iron. Many microorganisms have been isolated that transform iron through respiratory processes and participate in arsenic release by dissolution of As-bearing iron hydroxides. Shewanella alga strain BrY is a good example of a bacterial strain that is able to release arsenate from the mineral scorodite $\left(\mathrm{FeAsO} \mathrm{A}_{4} \cdot 2 \mathrm{H}_{2} \mathrm{O}\right)$ as a result of dissimilatory (i.e., respiratory) reduction of $\mathrm{Fe}$ (III) to $\mathrm{Fe}(\mathrm{II})$ (Cummings et al. 1999). Strain BrY was shown to solubilize the secondary minerals from sediments of mining-impacted Lake Coeur d'Alene. Another Shewanella, ANA-3 was found to cause arsenic mobilization from As-bearing $\mathrm{Fe}$ oxides due to $\mathrm{Fe}(\mathrm{III}) \rightarrow \mathrm{Fe}$ (II) dissimilatory reduction (Tufano et al. 2008). This strain was examined for its ability to promote desorption of both $\mathrm{As}(\mathrm{III})$ and $\mathrm{As}(\mathrm{V})$ from ferrihydrite, goethite and hematite, and substantial differences in the desorption of these two forms of arsenic were recorded. As(III), which is adsorbed to a greater extent, was desorbed more rapidly because it binds less strongly than $\mathrm{As}(\mathrm{V})$. The reduction of $\mathrm{As}(\mathrm{V})$ became dominant in the arsenic release process when $\mathrm{Fe}$ (III) reduction was decoupled. Despite these findings, it remains unclear whether arsenic mobilization under anaerobic conditions results from mineralogical changes as a 
consequence of bacterial iron reduction. Some recent studies have found that microbial-mediated reductive dissolution of arsenic-bearing ferric oxides cannot by itself cause arsenic release, but it contributes (combined to $\mathrm{As}(\mathrm{V})$ reduction) to arsenic release (Islam et al. 2005; Coker et al. 2006; Kocar et al. 2006; Pedersen et al. 2006). Weber et al. (2010) found that in a flooded polluted soil, the rate of $\mathrm{As}(\mathrm{V})$ reduction was controlled by the rate of microbial Fe(III) (hydr)oxide reduction.

\section{Arsenic resistance mechanisms}

Regardless of the mechanism of mineral dissolution, microbes involved in arsenic mobilization have to be resistant to soluble arsenic compounds. Both prokaryotes and eukaryotes are exposed to the toxic effects of arsenic compounds, but only a few (mostly microorganisms) have evolved resistance systems.

The uptake of arsenic by bacteria occurs via the glycerol and phosphate transport systems (Mukhopadhyay et al. 2002). Therefore, the primary mechanisms of arsenic resistance are based on the minimization of arsenic uptake by increasing the specificity of phosphate uptake $[\mathrm{As}(\mathrm{V})]$ and the glycerol transporter (aquaglyceroporin) [As(III)] (Cervantes et al. 1994; Sanders et al. 1997; Rosen and Liu 2009). Once arsenic has entered the cell, other defense mechanisms are activated. The most widespread mechanism of arsenic resistance in microorganisms is based on energydependent efflux of arsenite from the cell (Cervantes et al. 1994; Oremland and Stolz 2003). These systems employ an efflux protein (ArsB), which usually utilizes the energy from ATP hydrolysis catalyzed by an ATPase (ArsA) (Dey et al. 1994; Tisa and Rosen 1990). Systems based on ArsB efflux proteins can also protect the cell against arsenate, but in this case, prior reduction of $\mathrm{As}(\mathrm{V})$ to $\mathrm{As}(\mathrm{III})$ is required. This process is performed by a cytoplasmic reductase enzyme (ArsC) (Messens and Silver 2006) and is also involved in arsenic release in the environment. This was suggested by several authors, and in particular by Macur et al. (2001) for a mining tailing. It is noteworthy that genes encoding this enzyme have been found in almost all sequenced bacterial genomes.

Another process, often associated with detoxification, is arsenic methylation. The ability to produce methylated arsenic compounds has been detected in many species of fungi including Scopulariopsis brevicaulis (Challenger 1945), Candida humicola (Cox and Alexander 1973), Penicillium sp. (Huysmans and Frankenberger 1991), and bacteria such as Aeromonas sp. and Flavobacterium sp. (Wong et al. 1977), Corynebacterium sp., Escherichia coli, Proteus sp., Pseudomonas sp. Achromobacter sp., Alcaligenes sp., Nocardia sp. and Rhodopseudomonas palustris (Bentley and Chasteen 2002), and even in archaea (Methanobacterium bryantii;
McBride and Wolfe 1971). Interestingly, microbial methylation of arsenic compounds is very similar to the process carried out in animal tissues (Silver and Phung 1996). In fungal cells and animal tissues, the methyl group donor is $S$ adenosylmethionine and the methylation product is dimethylarsinic acid (cacodylic acid). In bacteria, the methyl donor may also be $S$-adenosylmethionine (Qin et al. 2006) or alternatively methyl-cobalamin (Bentley and Chasteen 2002). In all cases, the methylation process is catalyzed by methyltransferase, an essential cytoplasmic protein, which uses thioredoxin (Trx) as a reducing agent (Silver and Phung 1996). It should be highlighted that the methylation of arsenic compounds is not a universal mechanism of resistance to arsenic, and for some microorganisms, methylated forms of arsenic are more toxic than the unmethylated form (Stolz et al. 2006). On the other hand, little is known about the reverse process, namely the demethylation of organic derivatives of arsenic.

\section{The arsenic biogeochemical cycle in mining environments}

Based on current knowledge about mineral-microbe interactions and experimental data relating to microbially mediated dissolution of arsenic-bearing minerals, we propose a conceptual model for microbial transformation of arsenic in mining environments (Fig. 1). Dissolution of primary arsenic minerals is mediated by both chemolithoautotrophs, that use As, Fe or S as an energy source, as well as arsenicresistant microbes, which produce extracellular metabolites for nutrient uptake. Secondary arsenic minerals, formed by $\mathrm{As}(\mathrm{III})$ and/or $\mathrm{As}(\mathrm{V})$ adsorption on ferrous oxides, are dissolved by reductive dissolution mediated by dissimilatory arsenate- or iron-reducing bacteria. Soluble arsenite and arsenate are subjected to constant transformation, which is dependent on local microbial communities, structures and environmental conditions. Volatile arsenic compounds, which can be produced from minerals as well as watersoluble salts, also have a microbial origin (Fig. 1).

\section{The use of microorganisms in mining}

The previous section examined the potential use of microbes in mining. In this context, the frequent occurrence of arsenic as an impurity in many metal-rich sulfide deposits is problematic. The presence of arsenic in mineral concentrates drastically decreases their economic value and can cause a number of difficulties associated with their exploitation (Breed et al. 2000). A high arsenic content causes metallurgical problems connected with troublesome metal extraction and the difficulty in recovering a final product of high 


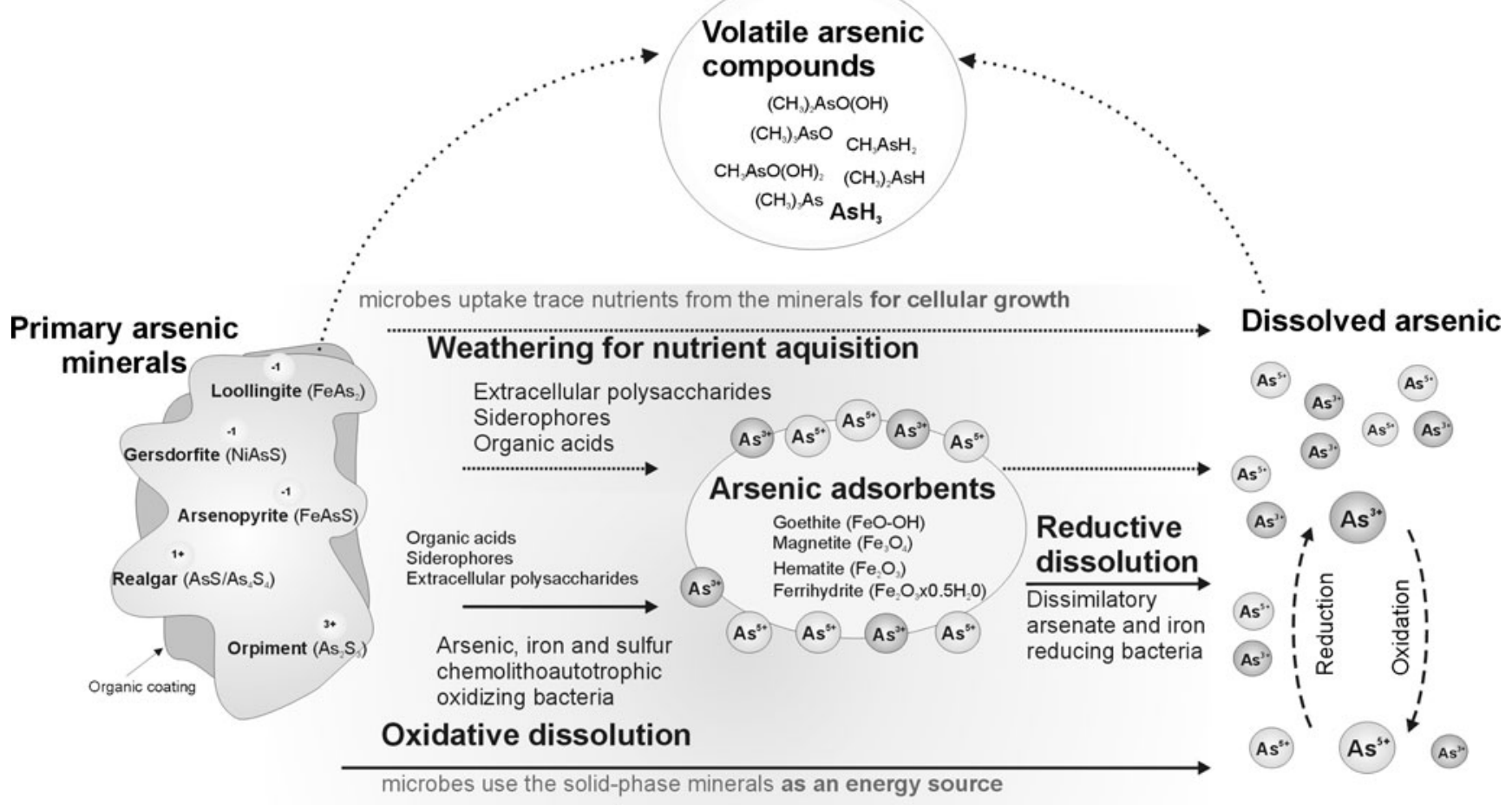

Fig. 1 Microbial transformation of arsenic in mining environments

purity. In addition, the presence of arsenic in deposits may result in environmental problems due to hazardous emissions produced by pyrometallurgical treatment. During the roasting and smelting of arsenic-bearing ores and concentrates, arsenic oxides, volatile compounds and large volumes of off-gas constituents are generated.

In the following sections, we discuss common biomining activities involved in the processing of arsenic-bearing minerals as well as the bioremediation of arsenic-contaminated sites.

\section{Bioleaching and biooxidation of arsenic-bearing minerals}

Biomining activities that result in the release of metals from minerals comprise two main processes: bioleaching and biooxidation. The first process is based on the conversion of insoluble metal sulfides [such as covellite (CuS) or chalcocite $(\mathrm{Cu} 2 \mathrm{~S})]$ to water-soluble metal sulfates (such as copper sulfate). The second process utilizes biooxidation as a pretreatment, whereby the desired metal remains in the rock, but the mineral structure is converted to allow better penetration of chemicals that can solubilize it. A good example of this type of biooxidation is the BIOX ${ }^{\mathrm{TM}}$ process, which was the first such method for the pretreatment of refractory gold sulfide ores such as arsenopyrite (Rawlings 2011).
During the biooxidation process, iron, arsenic, and sulfur are removed from gold deposits so that the gold that remains in the mineral is more easily extracted by subsequent treatment with cyanide (Rawlings 2005). Biooxidation is more time consuming than roasting, but it has the advantages of being less expensive and safer for the environment. Roasting produces harmful airborne arsenic compounds such as arsenic trioxide (Grund et al. 2008). Biooxidation processes also generate potentially toxic compounds, so some safeguards are required. In the commonly used commercial process $\mathrm{BIOX}^{\mathrm{TM}}$, the solution containing arsenic is neutralized using limestone or lime in two stages. In the first, arsenite is precipitated as stable ferric arsenate by adjusting the $\mathrm{pH}$ to $4-5$, while in the subsequent second step, the $\mathrm{pH}$ is increased to 6-8 to enhance the co-precipitation of iron and arsenic (van Aswegen et al. 2007). Another technology, developed for the treatment of concentrates not suitable for commercial smelting due to their content of deleterious elements, such as arsenic, is BioCOPTM (Batty and Rorke 2006). This technology was designed to remove a base metal from its concentrate, and is based on bioleaching mechanisms in which oxidation of the mineral (such as chalcopyrite) solubilizes the base metal (such as copper) associated with it. The BioCOPTM process utilizes thermophilic microorganisms operating at temperatures of up to $80{ }^{\circ} \mathrm{C}$ to leach copper sulfide mineral concentrates. A semicommercial demonstration plant employing thermophiles to solubilize a copper-arsenic concentrate, was successfully 
implemented by Alliance Copper at Chuquicamata in Chile (Domic 2007).

Makita et al. (2004) demonstrated the use of Acidithiobacillus ferrooxidans for the partial removal of arsenic (occurring in the form of FeAsS) from galena (PbS) concentrate. Galena and arsenopyrite were totally oxidized, but only $22-33 \%$ of arsenic from the original content in the mineral was retained in the solution. Oxidized galena formed an anglesite $\left(\mathrm{PbSO}_{4}\right)$ concentrate and the rest of the biooxidized arsenic was precipitated in the form of amorphous compounds. Biooxidation processes for the pretreatment of copper minerals such as enargite have also been tested (Curreli et al. 1997; Escobar et al. 2000; Muñoz et al. 2006). However, in contrast to the biooxidation of arsenopyrite, a minor amount of enargite oxidation was observed (Corkhill et al. 2008). Moreover, according to the estimations of Watling (2006), bioleaching of enargite may require months to years to achieve significant results.

\section{Bioprocesses for treating arsenic-contaminated waters}

The release of arsenic from minerals due to mining operations directly contributes to the pollution of drinking (ground and surface) water sources. Thus, the recovery of arsenic from mine waters is a major environmental issue that has to be addressed by the mining industry. Depending on the geochemistry of the contaminated waters, various physical and chemical remediation methods have been proposed. Most of these procedures, including filtration, coagulation, ion exchange and inverse osmosis, which are the most effective (Bissen and Frimmel 2003), require the conversion of $\mathrm{As}(\mathrm{III})$ to $\mathrm{As}(\mathrm{V})$ by powerful oxidants such as potassium permanganate, hydrogen peroxide or ozone. However, the use of chemical oxidants has limitations, mainly associated with side effects such as environmental pollution with these oxidizing compounds. Microbiological methods represent an environmentally harmless and economically viable alternative.

Non-specific chemical oxidation processes may be replaced by specific arsenite oxidation mediated either by previously characterized arsenite-oxidizing bacterial strains or by natural bacterial consortia. A procedure for using bacteria for arsenite oxidation in arsenic-contaminated wastewaters $(100 \mathrm{mg} / \mathrm{l})$ was proposed by Simeonova et al. (2005). Their approach was based on As(III) oxidation mediated by Herminiimonas arsenicoxydans immobilized on Ca-alginate beads. Lievremont et al. (2003) described a two stage process in which arsenite oxidation is performed by $H$. arsenicoxydans immobilized on chabazite, followed by arsenate adsorption on kutnahorite, a low cost adsorbent. A similar two-step approach was also presented by Mokashi and Paknikar (2002), who utilized arsenite oxidation mediated by Microbacterium lacticum immobilized on brick pieces packed in a glass column, followed by the removal of $\mathrm{As}(\mathrm{V})$ with zero valent iron or activated charcoal (an arsenate adsorbent). Biological As(III) oxidation systems are efficient in the laboratory over a wide range of arsenite concentrations, but the effective removal of the $\mathrm{As}(\mathrm{V})$ produced by this process is required before in situ implementation is possible.

Some proposed methods for the microbiological treatment of arsenic-containing water also include the use arsenate-reducing bacteria. In environments where deposits of sulfides and arsenic are strongly sequestered, microbial reduction of $\mathrm{As}(\mathrm{V})$ can lead to the remobilization of the arsenic. As(III) is then removed by precipitation or complexion with sulfide. Microorganisms that can promote the joint reduction of arsenate and sulfate play an important role in such precipitation processes. For example, the two strains Desulfomicrobium Ben-RB and Desulfotomaculum auripigmentum can concomitantly reduce $\mathrm{As}(\mathrm{V})$ to $\mathrm{As}(\mathrm{III})$ and $\mathrm{S}$ (VI) to $\mathrm{S}(\mathrm{II})$, which leads to the formation of both intracellular and extracellular arsenic trisulfide precipitates (Newman et al. 1997). The potential application of sulfate-reducing bacteria (SRB) in arsenic bioremediation has also been described. SRB oxidize simple organic compounds by utilizing sulfate as an electron acceptor. The sulfides and alkalinity resulting from this process provide favorable conditions for the sequestration of arsenic. From their studies on such a system, Teclu et al. (2008) demonstrated the effectiveness of arsenic removal by precipitation of the metalloid as metal sulfide and they also showed that SRB cells can remove significant quantities of $\mathrm{As}(\mathrm{III})$ and $\mathrm{As}(\mathrm{V})$ by biosorption. Luo et al. (2008) reported the use of an ethanol-fed sulfatereducing bioreactor system to remove arsenic, selenium and sulfate from neutral to alkaline mine wastewater in the presence of iron. The iron helped to prevent the formation of high $\mathrm{H}_{2} \mathrm{~S}$ concentrations by removing this sulfide as FeS. In landfill sites, the induction of reducing conditions in groundwater has the potential to immobilize arsenic. Keimowitz et al. (2007) showed that the use of in situ enhancement of sulfate reduction to immobilize dissolved arsenic is a viable remediation strategy that merits further investigation.

Battaglia-Brunet et al. (2006) have studied biogeochemical phenomena involved in the process of natural arsenic removal from mine drainage water. They showed that indigenous bacteria are able to participate in arsenic removal from neutral or slightly acidic (pH6.0-7.0) mine water under both anaerobic and aerobic conditions. Using the indigenous microbial population, $99 \%$ of $\mathrm{As}(\mathrm{III})$ and $91 \%$ of $\mathrm{As}(\mathrm{V})$ removal was observed in the column experiment. These results formed the basis for the development of an in situ passive treatment process that significantly improved the quality of the discharge effluent of mine waters. 
Constructed wetlands represent another strategy for ground and surface water cleaning. The main As removal processes in these wetlands are precipitation, coprecipitation and sorption, often mediated by microorganisms. Arsenic can be precipitated as arsenosulfides (reduced species) or as arsenates (oxidized species), coprecipitated with other sulfides or metal oxides (especially Fe), or it can be sorbed onto the wetland matter (Lizama et al. 2011). The most important factors that affect the removal of As are $\mathrm{pH}$ and the presence of $\mathrm{Fe}$ and $\mathrm{S}$. However, temperature, the available sources of carbon and dissolved oxygen are also important for the growth of microorganisms (Lizama et al. 2011). Manipulation of these key factors may be used to enhance particular removal processes. Constructed wetlands are cost-effective natural systems that have been successfully used to remove various pollutants, including arsenic (Marchand et al. 2010).

\section{Conclusions}

In this work, we have reviewed the biogeochemistry of arsenic and examined its relevance to the extraction of metals from arsenic-bearing ore, the development of biomining and the environmental risks connected with the exploitation of these minerals as well as other anthropogenic activities that are sources of arsenic pollution.

The metallurgical industry exploits arsenic-bearing minerals for the recovery of other metals (gold, silver, copper, difficulties in metal extraction and the recovery of a final product of high purity, and (2) contamination of the environment. Biomining of sulfidic ores containing precious metals (gold, silver) is now practiced on an industrial scale. Arsenopyrite and pyrite are selectively removed by bioleaching with acidophilic bacteria (e.g., Acidithiobacillus ferrooxidans) facilitating the extraction of gold and silver by cyanidation (Rawlings 2011). Biomining represents a successful application of biohydrometallurgy, but it creates considerable environmental problems that require special attention. Solubilized arsenic compounds must be reimmobilized and safely stored to prevent pollution dissemination. Environmental concerns are currently a serious drawback of biomining processes, but they are still more environmentally safe than traditional mining and smelting. Interestingly, the biomining microorganisms that contribute to these environmental problems may also be used in remediation strategies, discussed by Lievremont et al. (2009). Most biotechnologies for the remediation of contaminated soil and water have yet to be implemented, and their development and efficient application represents a major challenge.

Acknowledgments This work was supported by the Polish Ministry of Science and Higher Education in the form of grant Juventus Plus No.
0079/P01/201070. We also gratefully acknowledge the help of Dr. John Gittins for his critical reading of the manuscript and English correction.

Open Access This article is distributed under the terms of the Creative Commons Attribution License which permits any use, distribution, and reproduction in any medium, provided the original author(s) and the source are credited.

\section{References}

Aiken AM, Peyton BM, Apel WA, Petersen JN (2003) Heavy metal induced inhibition of Aspergillus niger reductase: applications for rapid contaminant detection in aqueous samples. Anal Chim Acta 480:131-142

Banfield JF, Barker WW, Welch SA, Taunton A (1999) Biological impact on mineral dissolution: application of the lichen model to understanding mineral weathering in the rhizosphere. Proc Natl Acad Sci USA 96:3404-3411

Barker WW, Welch SA, Banfield JF (1997) Biochemical weathering of silicate minerals. In: Banfield JF, Nealson KH (eds) Geomicrobiology: interactions between microbes and minerals, vol 35. Mineralogical Society of America, Washington, pp 35-79

Battaglia-Brunet F, Joulian C, Garrido F, Dictor MC, Morin D, Coupland K, Johnson DB, Hallberg KB, Baranger P (2006) Oxidation of arsenite by Thiomonas strains and characterization of Thiomonas arsenivorans sp. nov. Antonie Van Leeuwenhoek 89:99-108

Batty JD, Rorke GV (2006) Development and commercial demonstration of the BioCOPTM thermophile process. Hydrometallurgy 83:83-89

Bennett PC, Melcer ME, Siegel DI, Hassett JP (1988) The dissolution of quartz in dilute aqueous solutions of organic acids at $25{ }^{\circ} \mathrm{C}$. Geochem Cosmochim Acta 52:1521-1530

Bentley R, Chasteen TG (2002) Microbial methylation of metalloids: arsenic, antimony, and bismuth. Microbiol Mol Biol Rev 66:250-271

Bissen M, Frimmel FH (2003) Arsenic - a review: part II. Oxidation of arsenic and its removal in water treatment. Acta Hydrochim Hydrobiol 31:97-107

Brantley SL, Liermann LJ, Bau M (2001) Uptake of trace metals and rare earth elements from hornblende by a soil bacterium. Geomicrobiol J 18:37-61

Breed AW, Dempers CJN, Hansford GS (2000) Studies on the bioleaching of refractory concentrates. Journal of the South African Institute of Mining and Metallurgy November/December, 389-398

Cervantes C, Ji G, Ramirez JL, Silver S (1994) Resistance to arsenic compounds in microorganisms. FEMS Microbiol Rev 15:355-367

Challenger F (1945) Biological methylation. Chem Rev 36:315-361

Chen P, Yan L, Leng F, Nan W, Yue X, Zheng Y, Feng N, Li H (2011) Bioleaching of realgar by Acidithiobacillus ferroxidans using ferrous iron and elemental sulfur as the sole and mixed energy source. Bioresource Technol 102:3260-3267

Coker VS, Gault AG, Pearce CI, Van der Laan G, Telling ND, Charnock JM et al (2006) XAS and XMCD evidence for species-dependent partitioning of arsenic during microbial reduction of ferrihydrite to magnetite. Environ Sci Technol 40:7745-7750

Collinet MN, Morin D (1990) Characterisation of arsenopyrite oxidising Thiobacillus. Tolerance to arsenite, arsenate, ferrous and ferric iron. Antonie van Leeuwenhoek 57:237-244

Corkhill CL, Vaughan DJ (2009) Arsenopyrite oxidation - a review. Appl Geochem 24:2342-2361

Corkhill CL, Wincott PL, Lloyd JR, Vaughan DJ (2008) The oxidative dissolution of arsenopyrite (FeAsS) and enargite $\left(\mathrm{Cu}_{3} \mathrm{AsS}_{4}\right)$ by Leptospirillum ferrooxidans. Geochim Cosmochim Acta 72:5616-5633 
Cox DP, Alexander M (1973) Production of trimethylarsine gas from various arsenic compounds by three sewage fungi. Bull Environ Contam Toxicol 9:84-88

Cummings DE, Caccavo FJ, Fendorf S, Rosenweig RF (1999) Arsenic mobilization by the dissimilatory Fe(III)-reducing bacterium Shewanella alga BrY. Environ Sci Technol 33:723-729

Curreli L, Loi G, Peretti R, Rossi G, Trois P, Zucca A (1997) Gold recovery enhancement from complex sulphide ores through combined bioleaching and cyanidation. Miner Eng 10:567-576

Dey S, Dou D, Tisa LS, Rosen BP (1994) Interaction of the catalytic and the membrane subunits of an oxyanion-translocating ATPase. Arch Biochem Biophys 311:418-424

Domic EM (2007) A review of the development and current status of copper bioleaching operations in Chile: 25 years of successful commercial implementation. In: Rawlings DE, Johnson DB (eds) Biomining. Springer-Verlag, Berlin, pp 81-95

Drahota P, Filippi M (2009) Secondary arsenic minerals in the environment: a review. Environ Int 35:1243-1255

Drever JI, Stillings LL (1997) The role of organic acids in mineral weathering. Coll Surf 120:167-181

Drewniak L, Matlakowska R, Sklodowska A (2008) Arsenite and arsenate metabolism of Sinorhizobium sp. M14 living in the extreme environment of the Zloty Stok gold mine. Geomicro J $25: 363-370$

Drewniak L, Matlakowska R, Rewerski B, Sklodowska A (2010) Arsenic release from gold mine rocks mediated by the activity of indigenous bacteria. Hydrometallurgy 104:437-442

Escobar B, Huenupi E, Godoy I, Wiertz JV (2000) Arsenic precipitation in the bioleaching of enargite by Sulfolobus BC at $70{ }^{\circ} \mathrm{C}$. Biotechnol Lett 22:205-209

Fisher E, Dawson AM, Polshyna G, Lisak J, Crable B, Perera E, Ranganathan M, Thangavelu M, Basu P, Stolz JF (2008) Transformation of inorganic and organic arsenic by Alkaliphilus oremlandii sp. nov. strain OhILAs. Ann N Y Acad Sci 1125:230-241

Gihring TM, Banfield JF (2001) Arsenite oxidation and arsenate respiration by a new Thermus isolate. FEMS Microbiol Lett 204:335-340

Grund SC, Hanusch K, Wolf HU (2008) Arsenic and arsenic compounds. Chapter 7. In Ullmann's encyclopedia of industrial chemistry. doi:10.1002/14356007.a03 113

Hackl RP, Jones L (1997) Bacterial sulfur oxidation pathways and their effect on the cyanidation characteristics of biooxidised refractory gold concentrates. In: Proc. 16th Int. Biohydrometall. Symp., Australian Mineral Foundation, Glenside, South Australia, pp. M14.2.1-M142.10.

Han FX, Su Y, Monts DL, Plodinec MJ, Banin A, Triplett GE (2003) Assessment of global industrial-age anthropogenic arsenic contamination. Naturwissenschaften 90:395-401

Hoang TH, Ju-Yong K, Sunbaek B, Kyoung-Woong K (2010) Source and fate of as in the environment. Geosystem engineering 13:35-42

Hoeft SE, Kulp TR, Stolz JF, Hollibaugh JT, Oremland RS (2004) Dissimilatory arsenate reduction with sulfide as electron donor: experiments with mono lake water and isolation of strain MLMS1, a chemoautotrophic arsenate respirer. Appl Environ Microbiol 70:2741-2747

Huysmans KD, Frankenberger WT (1991) Evolution of trimethylarsine by a Penicillium sp. isolated from agricultural evaporation pond water. Sci Total Environ 105:13-28

Islam FS, Pederick RL, Gault AG, Adams LK, Polya DA, Charnock JM et al (2005) Interactions between the $\mathrm{Fe}(\mathrm{III})$-reducing bacterium Geobacter sulfurreducens and arsenate, and capture of the metalloid by biogenic Fe(II). Appl Environ Microbiol 71:8642-8648

Johnson DB (2003) Chemical and microbiological characteristics of mineral spoils and drainage waters at abandoned coal and metal mines. Water Air Soil Pollut Focus 3:47-66
Keimowitz AR, Mailloux BJ, Cole P, Stute M, Simpson HJ, Chillrud SN (2007) Laboratory investigations of enhanced sulfate reduction as a groundwater arsenic remediation strategy. Environ Sci Technol 41:6718-6724

Kocar BD, Herbel MJ, Tufano KJ, Fendorf S (2006) Contrasting effects of dissimilatory iron(III) and arsenic(V) reduction on arsenic retention and transport. Environ Sci Technol 40:6715-6721

Konhauser K (2007) Introduction to geomicrobiology. Blackwell Publishing, Oxford, pp 192-234

Krafft T, Macy JM (1998) Purification and characterization of the respiratory arsenate reductase of Chrysiogenes arsenatis. Eur J Biochem 255:647-653

Laverman AM, Blum JS, Schaefer JK, Phillips E, Lovley DR, Oremland RS (1995) Growth of strain SES-3 with arsenate and other diverse electron acceptors. Appl Environ Microbiol 61:3556-3561

Lievremont D, N'Negue MA, Behra P, Lett MC (2003) Biological oxidation of arsenite: batch reactor experiments in presence of kutnahorite and chabazite. Chemosphere 51:419-428

Lievremont D, Bertin PN, Lett MC (2009) Arsenic in contaminated waters: biogeochemical cycle, microbial metabolism and biotreatment processes. Biochimie 91:1229-1237

Lis J, Pasieczna A (1995) The geochemical atlases of Poland 1:2 500 000. Polish Geological Institute, Warsaw, p 74 (in Polish)

Lizama AK, Fletcher TD, Sun G (2011) Removal processes for arsenic in constructed wetlands. Chemosphere 84:1032-1043

Luo Q, Tsukamoto TK, Zamzow KL, Miller GC (2008) Arsenic, selenium, and sulfate removal using an ethanol-enhanced sulfate-reducing bioreactor. Mine Water Environ 27:100-108

Macur RE, Wheeler JT, McDermott T, Inskeep WP, (2001) Microbial populations associated with the reduction and enhanced mobilization of arsenic in mine tailings. Environ Sci Technol 35:36763682 .

Mailloux BJ, Alexandrova E, Keimowitz AR, Wovkulich K, Freyer GA, Herron M, Stolz JF, Kenna TC, Pichler T, Polizzotto ML, Dong H, Bishop M, Knappett PSK (2009) Microbial mineral weathering for nutrient acquisition releases arsenic. Applied and Environ Microbiol 75:2558-2565

Makita M, Esperon M, Pereyra B, Lopez A, Orrantia E (2004) Reduction of arsenic content in a complex galena concentrate by Acidithiobacillus ferrooxidans BMC Biotechnol 4:22

Malik A (2004) Metal bioremediation through growing cells. Environ Int 30:261-278

Marchand L, Mench M, Jacob DL, Otte ML (2010) Metal and metalloid removal in constructed wetlands, with emphasis on the importance of plants and standardized measurements: a review. Environ Pollution 158:3447-3461

McBride BC, Wolfe RS (1971) Biosynthesis of dimethylarsine by Methanobacterium. Biochemistry 10:4312-4317

Messens J, Silver S (2006) Arsenate reduction: thiol cascade chemistry with convergent evolution. J Mol Biol 362:1-17

Mokashi SA, Paknikar KM (2002) Arsenic (III) oxidizing Microbacterium lacticum and its use in the treatment of arsenic contaminated groundwater. Lett Appl Microbiol 34:258-262

Mukhopadhyay R, Rosen BP, Phung LT, Silver S (2002) Microbial arsenic: from geocycles to genes and enzymes. FEMS Microbiol Rev 26:311-325

Mullen DJE, Nowacki W (1972) Refinement of crystal-structures of realgar, AsS and orpiment, $\mathrm{As}_{2} \mathrm{~S}_{3}$. Zeitschrift Fur Kristallographie 136:48-65

Muller D, Lievremont D, Simeonova DD, Hubert JC, Lett MC (2003) Arsenite oxidase aox genes from a metal-resistant betaproteobacterium. J Bacteriol 185:135-141

Muñoz JA, Blázquez ML, González F, Ballester A, Acevedo F, Gentina JC, González P (2006) Electrochemical study of enargite bioleaching by mesophilic and thermophilic microorganisms. Hydrometallurgy 84:175-186 
Nair A, Juwarkar AA, Singh SK (2007) Production and characterization of siderophores and its application in arsenic removal from contaminated soil. Water Air Soil Poll 180:199-212

Newman DK, Beveridge TJ, Morel F (1997) Precipitation of arsenic trisulfide by Desulfotomaculum auripigmentum. Appl Environ Microbiol 63:2022-2028

Newman DK, Ahmann D, Morel FM (1998) A brief review of microbial arsenate respiration. Geomicrobiol J 15:255-268

O'Day PA (2006) Chemistry and mineralogy of arsenic. Elements 2:77-83

O’Day PA, Vlassopoulos D, Root R, Rivera N (2004) The influence of sulfur and iron on dissolved arsenic concentrations in the shallow subsurface under changing redox conditions. Proc Natl Acad Sci U S A 101:13703-13708

Oremland RS, Stolz JF (2003) The ecology of arsenic. Science 300:939-944

Oremland RS, Hoeft SE, Santini JM, Bano N, Hollibaugh RA, Hollibaugh JT (2002) Anaerobic oxidation of arsenite in Mono Lake water and by a facultative, arsenite oxidizing chemoautotroph, strain MLHE-1. Appl Environ Microbiol 68:4795-4802

Paez-Espino D, Tamames J, de Lorenzo V, Canovas D (2009) Microbial responses to environmental arsenic. Biometals 22:117-130

Pedersen HD, Postma D, Jakobsen R (2006) Release of arsenic associated with the reduction and transformation of iron oxides. Geochim Cosmochim Acta 70:4116-4129

Peyton B, Apel WA (2005) Siderophore influence on the mobility of both radionuclides and heavy metals. INRA Informer 5:2-4

Plant JA, Kinniburgh DG, Smedley PL, Fordyce FM, Klinck BA (2005) Arsenic and selenium. In: Lollar BS (ed) Treatise on geochemistry, vol 9, Environmental geochemistry. Elsevier, London, pp 17-66

Qin J, Rosen BP, Zhang Y, Wang G, Franke S, Rensing C (2006) Arsenic detoxification and evolution of trimethylarsine gas by a microbial arsenite $S$-adenosylmethionine methyltransferase. Proc Natl Acad Sci USA 103:2075-2080

Rauschenbach I, Yee N, Häggblom MM, Bini E (2011) Energy metabolism and multiple respiratory pathways revealed by genome sequencing of Desulfurispirillum indicum strain S5. Environ Microbiol 13:1611-1621

Rawlings DE (2005) Characteristics and adaptability of iron- and sulfuroxidizing microorganisms used for the recovery of metals from minerals and their concentrates. Microbial Cell Factories 4:13

Rawlings DE (2011) Biomining (mineral bioleaching, mineral biooxidation). In: Reitner J, Thiel V (eds) Encyclopedia of geobiology. Springer, Netherlands, pp 182-185

Raymond KN, Muller G, Matzanke BF (1984) Complexation of iron by siderophore: a review of their solution and structural chemistry and biological function. In: Boschke FL (ed) Topics in current chemistry. Springer, Berlin, pp 49-102

Rhine ED, Phelps CD, Young LY (2006) Anaerobic arsenite oxidation by novel denitrifying isolates. Environ Microbiol 8:899-908

Rhine ED, Onesios KM, Serfes ME, Reinfelder JR, Young LY (2008) Arsenic transformation and mobilization from minerals by the arsenite oxidizing strain WAO. Environ Sci Technol 42:1423-1429

Rogers JR, Bennett PC (2004) Mineral stimulation of subsurface microorganisms: release of limiting nutrients from silicates. Chem Geol 203:91-108

Rogers JR, Bennett PC, Choi WJ (1998) Feldspars as a source of nutrients for microorganisms. Am Mineral 83:1532-1540

Rosen BP, Liu Z (2009) Transport pathways for arsenic and selenium: a minireview. Environ Int 35:512-515

Sadowski Z, Jazdzyk E, Farbiszewska T, Farbiszewska-Bajer J (2000) Biooxidation of mining tailings from Zloty Stok. Physicochem Probl Miner Process 3:47-56

Sanders OI, Rensing C, Kuroda M, Mitra B, Rosen BP (1997) Antimonite is accumulated by the glycerol facilitator GlpF in Escherichia coli. J Bacteriol 179:3365-3367
Santini JM, Sly LI, Schnagl RD, Macy JM (2000) A new chemolithoautotrophic arsenite-oxidizing bacterium isolated from a gold mine: phylogenetic, physiological, and preliminary biochemical studies. Appl Environ Microbiol 66:92-97

Silver S, Phung LT (1996) Bacterial heavy metal resistance: new surprises. Annu Rev Microbiol 50:753-789

Simeonova DD, Micheva K, Muller DAE, Lagarde F, Lett MC, Groudeva VI, Lievremont D (2005) Arsenite oxidation in batch reactors with alginate-immobilized ULPAs1 strain. Biotechnol Bioeng 91:441-446

Sorokin DY, Tourova TP, Sukhacheva MV, Muyzer G (2012) Desulfuribacillus alkaliarsenatis gen. nov. sp. nov., a deep-lineage, obligately anaerobic, dissimilatory sulfur and arsenate-reducing, haloalkaliphilic representative of the order Bacillales from soda lakes. Extremophiles 16:597-605

Stolz JF, Oremland RS (1999) Bacterial respiration of arsenic and selenium. FEMS Microbiol Rev 23:615-627

Stolz JF, Basu P, Santini JM, Oremland RS (2006) Arsenic and selenium in microbial metabolism. Annu Rev Microbiol 60:107-130

Sun WJ, Sierra-Alvarez R, Fernandez N, Sanz JL, Amils R, Legatzki A, Maier RM, Field JA (2009) Molecular characterization and in situ quantification of anoxic arsenite-oxidizing denitrifying enrichment cultures. FEMS Microbiol Ecol 68:72-85

Sun WJ, Sierra-Alvare R, Milner L, Field JA (2010) Anaerobic oxidation of arsenite linked to chlorate reduction. Appl Environ Microbiol 76:6804-6811

Switzer Blum J, Burns Bindi A, Buzzelli J, Stolz JF, Oremland RS (1998) Bacillus arsenicoselenatis, sp. nov., and Bacillus selenitireducens, sp. nov.: two haloalkaliphiles from Mono Lake, California that respire oxyanions of selenium and arsenic. Arch Microbiol 171:19-30

Teclu D, Tivchev G, Laing M, Wallis M (2008) Bioremoval of arsenic species from contaminated waters by sulphate-reducing bacteria. Water Res 42:4885-4893

Tisa LS, Rosen BP (1990) Molecular characterization of an anion pump: the ArsB protein is the membrane anchor for the ArsA protein. J Biol Chem 265:190-194

Tufano KJ, Reyes C, Saltikov CW, Fendorf S (2008) Reductive processes controlling arsenic retention: revealing the relative importance of iron and arsenic reduction. Environ Sci Technol 42:8283-8289

Uroz S, Calvaruso C, Turpault MP, Pierrat JC, Mustin C, Frey-Klett P (2007) Effect of the mycorrhizosphere on the genotypic and metabolic diversity of the bacterial communities involved in mineral weathering in a forest soil. Appl Environ Microbiol 73:3019-3027

van Aswegen PC, van Niekerk J, Olivier W (2007) The BIOX ${ }^{\mathrm{TM}}$ process for the treatment of refractory gold concentrates. In: Rawlings DE, Johnson DB (eds) Biomining. Springer-Verlag, Berlin, pp 1-32

Vaughan DJ (2006) Arsenic. Elements 2:71-75

Watling HR (2006) The bioleaching of sulphide minerals with emphasis on copper sulphides - a review. Hydrometallurgy 84:81-108

Weber FA, Hofacker AF, Kretzschmar R (2010) Temperature dependence and coupling of iron and arsenic reduction and release during flooding of a contaminated soil. Environ Sci Technol 44:116-122

Welch SA, Barker WW, Banfield JF (1999) Microbial extracellular polymers and plagioclase dissolution. Geochem Cosmochim Acta 63:1405-1419

Wong PTS, Chau YK, Luxon L, Bengert GA (1977) Methylation of arsenic in the aquatic environment. In: Hemphill DD (ed) Trace substances in environmental health, Part X. University of Missouri, Columbia, pp 100-105

Yarnell A, Washington EN (2003) Nature's tiniest geoengineers. Chem Eng News 81:24-25

Yudovic YE, Ketris MP (2005) Arsenic in coal: a review. Int J Coal Geology 61:141-196

Zobrist J, Dowdle PR, Davis JA, Oremland RS (2000) Mobilization of arsenite by dissimilatory reduction of adsorbed arsenate. Environ Sci Technol 34:4747-4753 